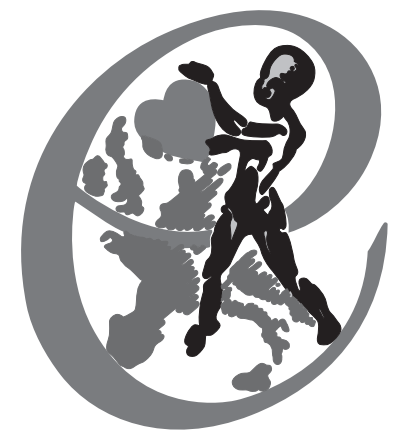

\title{
Association for European Paediatric Cardiology
}

\author{
Newsletter - August, 2011
}

\section{The 45th Annual Meeting in Granada}

The 45th Annual Meeting of the Association took place in Granada from May 18 to 20. It started with an Update-On Course on Interventional Cardiology. The course was attended by over 280 participants, and the chosen speakers gave an excellent update on the problems currently faced by cardiologists dealing with interventional cardiology. The teaching course gave an excellent opportunity to update knowledge on specific interventional treatments. The main topics included treatment of shunts, catheter treatment of right heart problems, and coarctation of the aorta. The update on course also gave an overview on the current state of hybrid procedures. Active participation, and lively discussions, proved that this teaching course was really needed. The Council of the Association appreciates the efforts of the Interventional working group in organising the course.

The Annual meeting itself was also a real success. It was attended by 920 participants. It started with a memorable opening session. The programme was both entertaining and artistic. Charles Mullins presented the Mannheimer Lecture, taking as his topic Odyssey with the development of therapeutic cardiac catheterisations. The Council of the Association is truly grateful to Maria del Mar, and their team for the excellent work they undertook in organising our 45th Annual Meeting.

The audience of over 900 attendees enjoyed highquality scientific sessions. The programme was designed together with the working groups. The major titles discussed were "The volume loaded right ventricle", "Pulmonary atresia and intact ventricular septum - new aspects on foetal diagnosis and management", "Imaging modalities - Current and future blessings", "Paediatric pulmonary hypertension", "Management of tachycardias in children with structurally normal hearts", "The role of imaging before, during and after intervention", "Transposition of the great arteries: long-term follow-up in atrial switch", "Quality of care", and "Pulmonary atresia with VSD and major aortopulmonary collarals".

The Japanese Society of Pediatric Cardiology and Cardiac Surgery organised a joint session with the Association on Complex left ventricular outflow tract obstruction. The Association had another joint session with the European Association of Cardiac thoracic Surgeons on "Transposition of the great arteries: Arterial switch controversies". The latter was accomplished in a new format: there were only two short presentations, the one by a cardiologist and the other by a surgeon, and thereafter an expert panel of four cardiologists and surgeons discussed the controversies and answered the questions of the audience. The session was interactive and inspired a lively discussion. This design of a session will also be used during the future meeting.

The session on successes and failures in the catheterisation laboratory was once again interactive and informative. We maintained our tradition of providing a morphologic demonstration, and this was well attended. Professor Carlos Ruiz gave the Keynote Closing Lecture. The eye-opening lecture on "Integration of multi-imaging information in the interventional suite: a key to advanced structural heart disease interventions" ended the scientific sessions. There were two moderated poster walks. This year, we received 703 submissions and accepted almost $60 \%$. Owing to the high quality of the abstracts and posters this year, we gave six prizes. We gave two Young investigator's Awards for the first time this year.

\section{Future Annual Meetings}

The 46th Annual Meeting will take place in Istanbul, and is scheduled for 23-26 May, 2012. The Annual Meeting of the Association will take place in London in 2013 and in Helsinki in 2014. We now invite our members and national societies to submit applications to host the Annual Meeting for 2015. 


\section{New Council member}

In Granada, André Bozio ended his period as PastPresident of the Association.

The members of the existing Council take this opportunity to thank André for all his work undertaken on their behalf as the President of the Association.

Last year, Katarina Hanséus from Lund, Sweden, was elected as the new Secretary-General Elect. She will replace Eero Jokinen as the Secretary-General in Granada. We wish Katarina the best of luck in this challenging Office.

The Association has also elected a new Council member. The Council has received a proposal for a new Councillor by more than five members from more than two countries by due time. Sylvie DiFilippo from Lyon, France, has been proposed by 11 members from a total of seven countries. She was also proposed by the French Society for Pediatric Cardiology. In addition, the Council also received another proposal for a Councillor's position. However, the member was proposed by two members from two countries, only, and he did not fulfil the criteria to be voted for as a Councillor. Sylvie DiFilippo was thus elected as the New Councillor.

The Council takes this opportunity to thank warmly all the retiring Council members, and to welcome equally warmly the new Council member and Officer, who we know will work equally hard for the benefit of the Association!

\section{Changes in the Constitution}

(a) The members accepted the Council's proposal to change the name of the Association during the Business Meeting on 19 May, 2011.

The new name is

Association for European Paediatric and Congenital Cardiology (AEPC)

Association Européenne de Cardiologie Pédiatrique et Congénitale (AEPC)

As the old name was

Association for European Paediatric Cardiology (AEPC)

Association Européenne de Cardiologie Pédiatrique (AEPC)

(b) During the Business Meeting, the members also accepted two changes in the Constitution:

(1) "When deemed appropriate by the AEPC Council, the Council will have the right, by majority vote, to co-opt additional members on to the Council to represent specific subspecialty groups (not already represented on the Council) for a maximum period of 3 years".
(2) "Chairman of the Educational Committee shall be an ex-officio member of the Professional Advisory Committee".

\section{New Working Group on Preventive Cardiology}

Last year, the members agreed to establish a new working group for Preventive Cardiology. The new working group had its first business meeting on 20 May, 2011. Eero Jokinen was elected as Chairman, Renate Oberhöffer as Secretary, and Robert DallaPozza as Treasurer. The new working group will have its first scientific meeting in Munich, 27 and 30 September, 2011. The new working group will also participate actively in the scientific programme of the next Annual Meeting, in the Europrevention meeting organised by the European Society of Cardiology in March, 2012, and in the World Congress in 2013.

\section{Message from the previous Secretary-General Eero Jokinen}

I am grateful to have been able to serve the Association as Secretary-General during the last 5 years. I have enjoyed every minute of it. It has been a pleasure to work in the largest global democratically governed Association of our discipline. The working groups that are the backbone of our association are active in organising teaching courses, the creation and updating of training recommendations, etc. Members who participate actively in the work of the working groups keep this Association vital.

The Council has worked actively for the best of the members. Below are some examples of the achievements of the council.

- The Council has created an extensive network with other associations. We have a close historical connection with ESC and especially with the GUCH working group. As surgeons are our important daily co-operators, the Association has tightened its connections with the European Association of Cardiothoracic Surgeons. We have also met with the Board of European Paediatric Academy, and we work actively in UEMS Cardiology Section. Our good connections with our Japanese sister organisation JSSPC are well visible during this Annual Meeting, as well. Furthermore, the Association has also created connections to the American College of Cardiology as past-President André Bozio was elected as a member of the Council of Congenital Heart Diseases within the American College of Cardiology. 
- These are only a few examples of our active networking on behalf of the members.

- Teaching is the main task of the Association. Therefore, the training recommendations in Paediatric Cardiology and its subspecialties will continuously be updated. Our aim is to harmonise training in European countries. For this reason, 2-3 basic teaching courses for the Juniors have been organised every year. The Council has established the Educational Committee to regulate this process.

- Cardiology in the Young is the Journal of the Association and the free annual subscription is a valuable membership benefit. The impact factor of this Journal has been constantly increasing. In addition to the Journal, webbased services are needed for rapid communication and to give online services to the members. We have renewed our web page last year and will change our database to the same server. These changes should correct most of the dysfunctions the members have possibly faced when using the online services. The new database is the engine of our online services. It enables completely new functions in our online services. The members have not found all the services of our new web page, for example,. only a few members have used the discussion forum that gives a really good opportunity for discussions with other members. In the future, new services like e-learning will be created.

I really appreciate the opportunity to work in the Council and with the members. I hope that I have partly been able to strengthen the democratic processes and translucency of decision making, to create new networks with other associations, and to make the Association more tolerant of different opinions. Open and free discussion and different views make our Association ever stronger. Our Association is the largest global democratic organisation in the field

of Congenital Cardiology. We should not look at the past but look forward and see the favourable future that is right in front of our eyes. Thank you all for the fruitful co-operation during all these years as the Secretary-General!

\section{Message from the new Secretary-General Katarina Hanséus}

Taking over the office as Secretary-General in AEPC after Eero Jokinen is an honour and a challenge. Eero has made an excellent contribution to AEPC, always being wise, efficient and very kind and friendly. During the last year, when I have served as Secretary-General Elect, Eero has been a good mentor, introducing me to the different tasks of the Office. I hope that during the years to come, our Association will continue to grow with regard to the number of members, teaching activities and collaboration within AEPC, and with other associations dedicated to the care of children and adolescents with cardiac disease.

The excellent meeting in Granada clearly demonstrated that at the same time as the advances regarding treatment of children and adolescents with cardiac disease continue, the health-care systems in many places face serious problems, related to economics, quality, and equality. As the largest global democratic organisation in the field of Congenital Cardiology, we may be able to take part in discussion about these issues.

However, my primary task will be to serve all of you members, and to facilitate and promote your involvement in the activities of AEPC. I am really looking forward to working together with all of you during my period as Secretary-General and I welcome all contacts during and between our meetings.

We hope you all a relaxing summer vacation!

Eero Jokinen

Previous Secretary-General
Katarina Hanséus Secretary-General 